\title{
PERCENTAGE CONTRIBUTION OF INPUTS FROM THE ATLANTIC, IRISH SEA, ENGLISH CHANNEL AND BALTIC INTO THE NORTH SEA DURING 1988: A TRACER-BASED EVALUATION USING ARTIFICIAL RADIONUCLIDES
}

\author{
P. BAILLY DU BOIS, P. GUÉGUÉNIAT, R. GANDON, R. LÉON and Y. BARON \\ Institut de Protection et de Sureté Nucléaire, Département de Protection de l'Environnement et des Installations, \\ Laboratoire d'Etudes Radioécologiques de la Façade Atlantique, IPSN-CEA, 50444 Beaumont Hague Cedex, France
}

\begin{abstract}
A sampling cruise carried out in the North Sea in July 1988 has enabled the construction of general maps showing the distribution of salinity and temperature as well as the activities of the radionuclides ${ }^{125} \mathrm{Sb},{ }^{137} \mathrm{Cs}$ and ${ }^{134} \mathrm{Cs}$. An inspection of the raw data and the distribution patterns so obtained shows the important role of meteorological fluctuations in the movement of near-surface waters throughout the North Sea.

A simple mixing model is used to interpret the North Sea dataset in terms of four contributory watermasses (the Atlantic, Irish Sea, English Channel and Baltic), each of which can be identified by its specific characteristics. Maps are drawn up which indicate the contribution factor in percentage of each of these water masses at all points in the North Sea to a precision better than $15 \%$. Pt is also possible to extract the contribution of direct fallout resulting from the Chernobyl accident; comparison with previously obtained results allows an evaluation of the rate of renewal of surface waters in the North Sea over a period of two years. In all areas, this value appears to be better than $75 \%$.
\end{abstract}

\section{INTRODUCTION}

Artificial radionuclides present as soluble species in seawater are of particular interest in oceanography due to their conservative behaviour; it is also possible to measure them at very low levels of activity. Given a knowledge of the source terms, the movements of labelled water masses can be monitored by means of these tracers.

The many radiotracer studies carried out in the North Sea have concentrated mainly on caesium 137 and 134, strontium 90 and technetium 99. These radionuclides are derived from the controlled release of soluble waste from the nuclear fuel reprocessing plants at Sellafield (U.K.) and La Hague (France), but also from the fallout of atmospheric nuclear testing and the accident at the Chernobyl power station (GUEGUÉNIAT et al., 1988; in press; KAUTSKY, 1973; 1976; 1988; JEFFERIES \& STEELE, 1989; NIES, 1990; NIES \& WEDEKIND,1988; AARKROG et al., 1983, 1987).

These data, which are supplemented by measurements of current flow, salinity and temperature (ICES, 1970; TAYLOR \& STEPHENS , 1983), as well as work on hydrodynamic modelling (DJENIDI et al., 1986; NIHOUL, 1980; VAN PAGEE et al., 1986; PRANDLE, 1978,1984; NIES, 1990; NIES \& WEDEKIND, 1988) have enabled a recognition of the overall movement of water masses in the North Sea. However, even though it is relatively easy to observe the spatial distribution of a single well-characterized source at a given moment in time, it is far more difficult to obtain a simultaneous picture of all the sources involved.

A cruise covering the whole North Sea area was carried out in 1988, two years after the accident at the Chernobyl power station in the Ukraine. At that time, the different pathways appeared to be sufficiently well characterized by dissolved radionuclides to enable the differentiation of sources on the scale of the North Sea. This also enabled the recognition of the distribution and mixing structure of the four main water masses entering the North Sea (Atlantic, Irish Sea, English Channel and Baltic waters). The overall picture obtained refers to a real situation developed under clearly marked meteorological conditions.

\section{MATERIALS AND METHODS \\ 2.1. SAMPLING CRUISE AT SEA}

The data presented in this article are derived from the Tramanor-I cruise, which was carried out in the North Sea from 5 to 29 July 1988 on board the IFREMER research vessel 'Cryos'. Fig. 1 gives the location of sampling stations. 


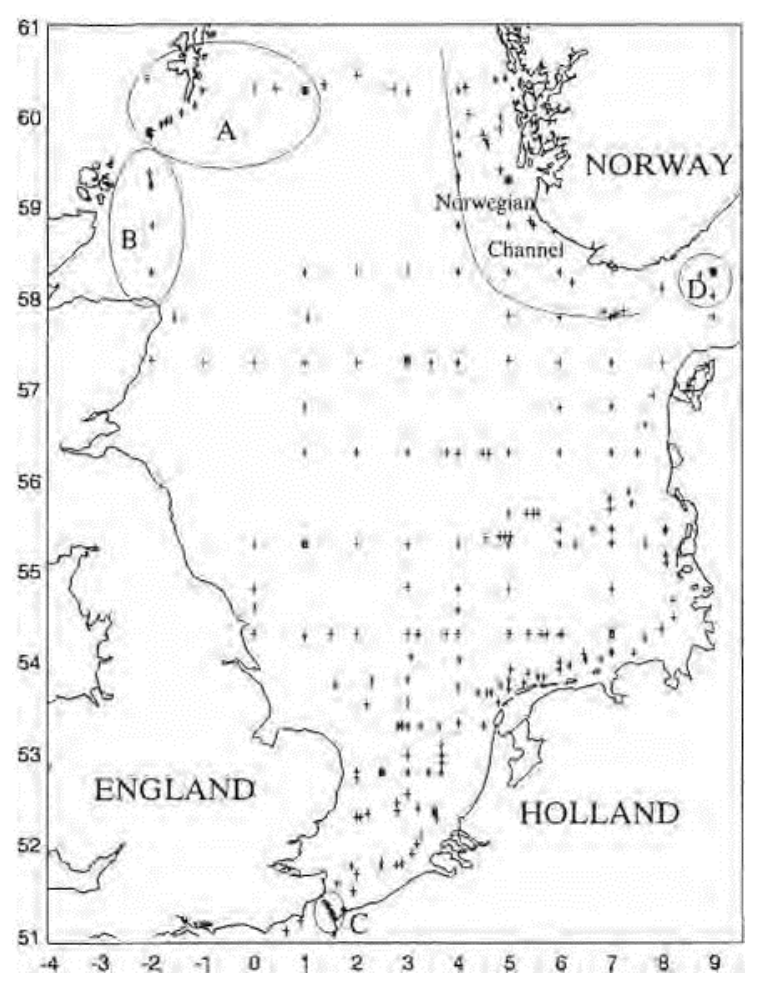

Fig. 1. Tramanor I cruise, location of sampling stations for surface seawater radioactivity $(+)$ and vertical profiles $(\bullet)$.

\subsection{ANALYTICAL TECHNIQUES}

\subsubsection{SALINITY AND TEMPERATURE}

Samples for the measurement of salinity, temperature and radioactivity were collected by pumping from a depth of $3 \mathrm{~m}$.

The measurements of salinity and temperature were performed continuously with a 'Seabird' operating system; this technique was employed in order to adapt the sampling step (for seawater radioactivity measurements) to hydrodynamic variations.

Profiles from ten hydrocast stations have enabled an evaluation of the stratification of the water masses in salinity and temperature (Fig. 1).

\subsubsection{DISSOLVED RADIONUCLIDES}

The activity of ${ }^{125} \mathrm{Sb}$ (half-life $2.88 \mathrm{y}$ ) was measured by gamma-ray spectrometry after extraction, with manganese dioxide at pH 3.5 (GANDON \& GUÉGUÉNIAT, 1992). The absorber was formed by the reduction of potassium permanganate $\left(\mathrm{KMnO}_{4}\right)$ with hydrogen peroxide $\left(\mathrm{H}_{2} \mathrm{O}_{2}\right)$, enabling the treatment of volumes of seawater ranging from 120 to $1200 \mathrm{dm}^{3}$. The concentration of suspended matter (SM) is always less than $50 \mathrm{mg}^{-\mathrm{dm}^{-3}}$; under such conditions, all the ${ }^{125} \mathrm{Sb}$ is in the soluble phase and more than $97 \%$ of this is fixed onto the $\mathrm{MnO}_{2}$ at $\mathrm{pH} 3.5$ (GANDON \& GUÉGUÉNIAT, 1992). Due to counting errors $(50,20$ and $10 \%$ for activities in the ranges 1.5-5, 5-15 and higher than $15 \mathrm{~Bq}-\mathrm{m}^{-3}$, respectively), an extraction yield correction was not applied (GANDON \& GUÉGUÉNIAT, 1992); the detection limit is $1.5 \mathrm{~Bq} \cdot \mathrm{m}^{-3}$.

${ }^{137} \mathrm{Cs}$ and ${ }^{134} \mathrm{Cs}$ (with respective half-lives of 30 and $2.2 \mathrm{y}$ ) were co-precipitated from the same seawater sample by adding Co-K ferrocyanide powder (at a concentration of $8.10^{-5} \mathrm{~g}-\mathrm{dm}^{-3}$ ) to the manganese dioxide absorber formed earlier during the extraction of antimony. This treatment brings about ion exchange with the caesium in solution. The measurement errors are 50,20 and $10 \%$ for activities in the ranges $0.7-1.5,1.5-10$ and $>10 \mathrm{~Bq}-\mathrm{m}^{-3}$, respectively, and the detection limit is 0.7

These three radiotracers are assumed to display a conservative behaviour in water masses away from the coast (SM contents <50 mg- $\mathrm{dm}^{-3}$; GANDON \& GUÉGUÉNIAT, 1992; MITCHELL \& STEELE, 1988; KAUTSKY, 1973) .

The measurement of gamma-activity levels in the extracted samples was undertaken by the Atomic Studies Group of the French Navy at Cherbourg. Some of the analyses were carried out directly on board ship with a Ge-Li detector (Y. Baron, French Navy) to obtain the location of water masses rapidly.

\subsection{MIXING MODEL}

\subsubsection{METHODOLOGY}

The salinity and temperature measurements at each point were processed manually in order to take better account of the sampling density (Fig. 2, a to f). The activity measurements were interpolated over the area of the North Sea, which was divided up into a regular grid (330 lines $\times 198$ columns) to facilitate the calculation as well as the visualization and comparison of results (Fig. 3, a to $\mathrm{c}$ ). This procedure was performed using the 'Kriging' method available with the 'SURFER' software package.

During the Tramanor-l cruise, the different water masses entering the North Sea (from the Atlantic, Irish Sea, English Channel and Baltic) were sufficiently well differentiated on the basis of the measured parameters (salinity, ${ }^{125} \mathrm{Sb},{ }^{137} \mathrm{Cs}$ and ${ }^{134} \mathrm{Cs}$ ) to allow an estimate of the respective contribution of the sources at all points on the grid.

As an initial hypothesis, it is assumed that the seawater collected at each sampling point in the North Sea is composed of a mixture of the four main water masses involved; their contributions are defined as follows:

-PAt $=$ contribution factor of waters from the Atlantic in \%

- Plr = contribution factor of waters from the Irish Sea in $\%$ 

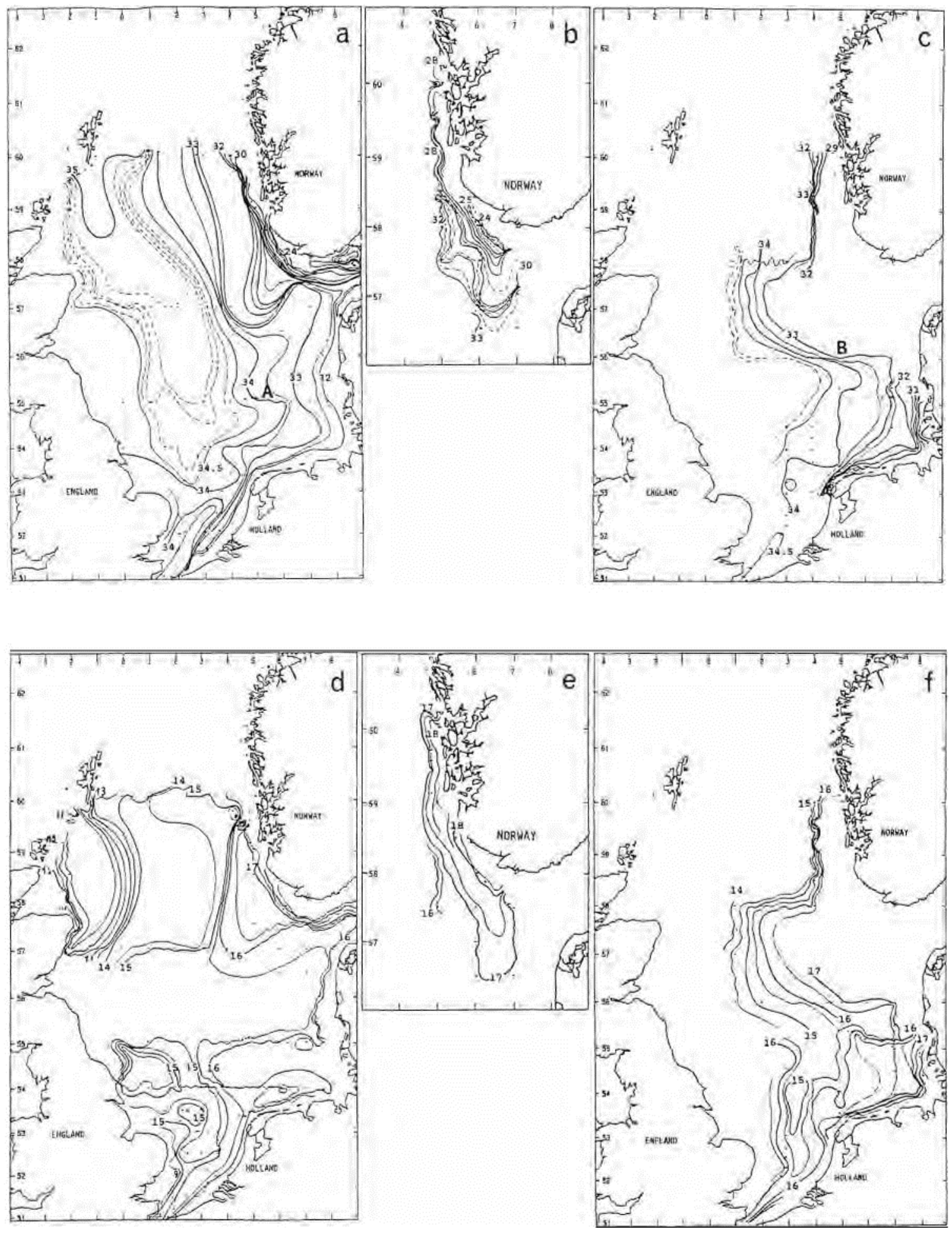

Fig. 2. Maps showing salinity (S) and temperature (T) measurements in the North Sea during July 1988: (a) S from 5 to 17 July 1988, (b) S from 17 to 19 July 1988, (c) S from 21 to 28 July 1988, (d) T from 5 to 17 July 1988, (e) T from 17 to 19 July 1988, (f) T from 21 to 28 July 1988. 

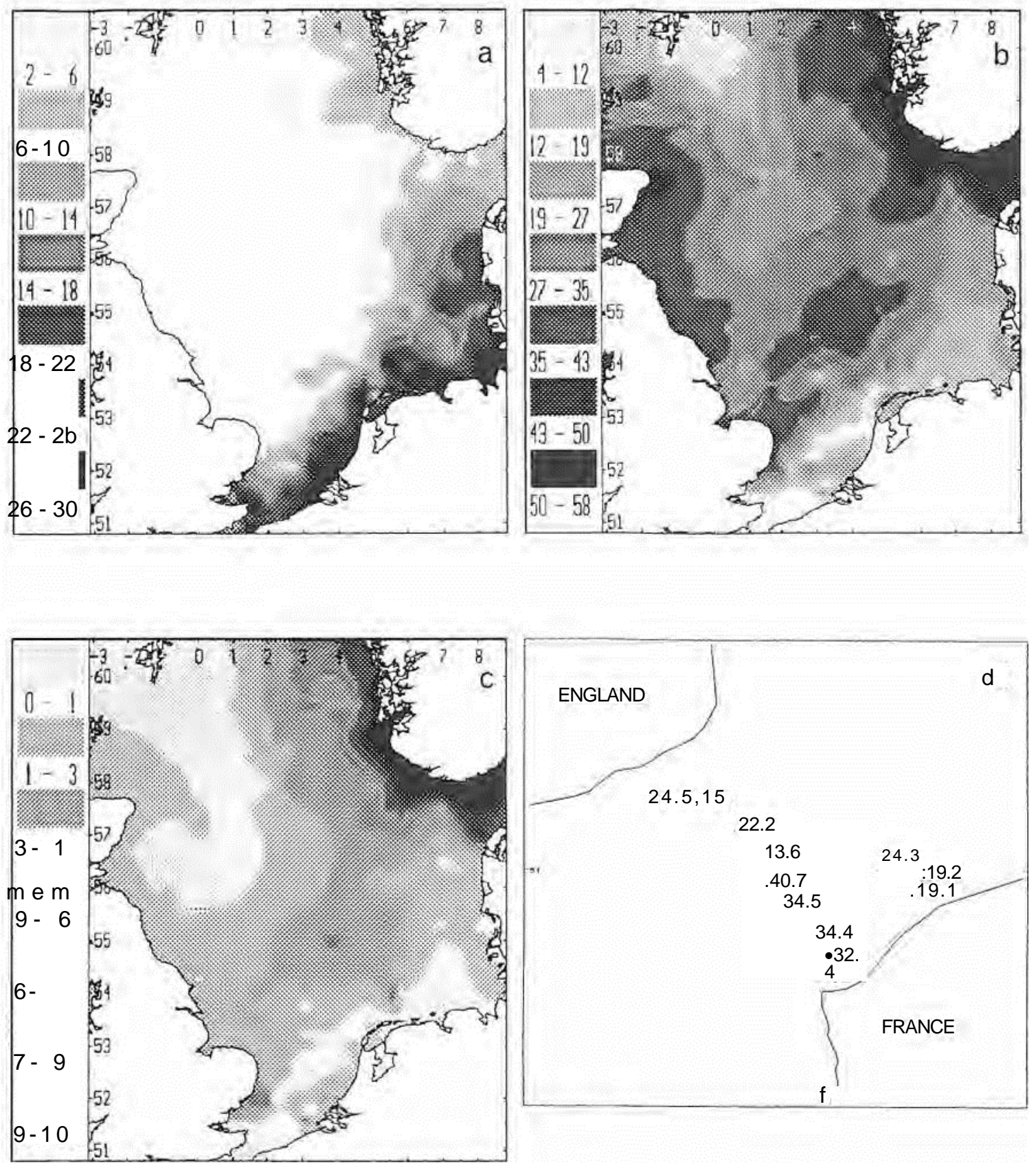

Fig. 3. Maps showing activities of dissolved radionuclides in the North Sea during July 1988: (a) Antimony-125 (dissolved) in (b) Caesium-137 (dissolved) in Bq.m-3 ${ }^{-3}$ (c) Caesium-134 (dissolved) in Bcpm ${ }^{-3}$, (d) Antimony-125 (dissolved) in detailed traverse in the Straits of Dover area.

-PMa $=$ contribution factor of waters from the English Channel in \%

$-\mathrm{PBa}=$ contribution factor of waters from the Baltic in \%

A simple system of four linear equations, where the four unknowns are the contributions of each input, can then be solved for all points on the grid used in the study. The four variables measured at each point of the grid are: Salinity, ${ }^{125} \mathrm{Sb},{ }^{137} \mathrm{Cs},{ }^{134} \mathrm{Cs}$.

The average values of these variables, which char- 
acterize the water masses entering the North Sea, are given in Table 1. The stations where the values were obtained are the most characteristic of the respective water masses and are located as follows: - Atlantic water masses (Fig. 1, Zone A): Stations to the north of latitude $59^{\circ} 30^{\prime}$, from longitude $2 \mathrm{~W}$ to longitude $1^{\circ} \mathrm{E}$, around the Shetlands.

- Irish Sea water masses (Fig. 1, Zone B): Stations to the west of longitude $1^{\circ} 30^{\prime} \mathrm{W}$, from latitude 5 T30' to latitude $59^{\circ} 30^{\prime}$, around the Orkney Islands.

- Channel water masses (Fig. 1 Zone C): The Dover Strait stations, between Calais and Dover.

- Baltic water masses (Fig. 1, Zone D): Stations of the Skagerrak located in the northern part of the line Hanstholm - Kristiansand, from latitude $57^{\circ} 30^{\prime}$ to the Norwegian coast; they represent the outflow of waters from the Baltic, mixed with water of the North Sea which has previously entered the Skagerrak.

The system of equations to be solved is:

Salin = SalinAt X PAt + Salin Ir X PIr + SalinMa X $\mathrm{PMa}+$ SalinBa X PBa

$125 \mathrm{Sb}=12 \mathrm{fi}{ }^{--}$SbAt X PAt $+{ }^{125}$ Sblr X PIr $+{ }^{125}$ SbMa X ${ }_{137} \mathrm{CS}={ }^{125} \mathrm{CbBa} X \mathrm{CBAa}$ X PAt + Csir X

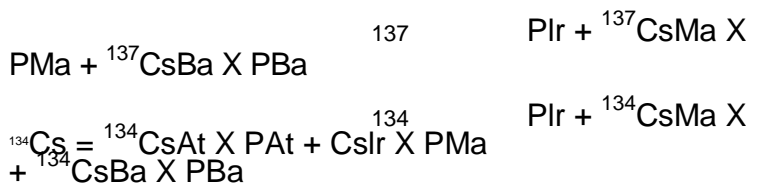

In this way, a map can be constructed which shows the contributions of each of the inputs to the North Sea (Atlantic, Irish Sea, English Channel and Baltic) (Fig. 4, a to d).

\subsubsection{FRESHWATER INPUT FROM THE BALTIC}

The characteristics attributed to the Baltic contribution correspond to those measured in samples from the Skagerrak outlet. Thus, the contributions of other waters passing through the Skagerrak are brought together at this one point.

In fact, only the continental run-off of freshwater coming into the Baltic needs to be considered in order to identify the water mass entering the North Sea through the Skagerrak. With such an approach, it is possible to identify the contributions of the English Channel, the Atlantic and the Irish Sea in the plume leaving the Skagerrak from the Baltic (the ${ }^{137} \mathrm{Cs}$ and ${ }^{134} \mathrm{Cs}$ activities in the freshwater are obtained by extrapolating the values measured in the Skagerrak towards lower salinities; Fig. 5). A further calculation was performed with this aim in view.

We here present a modification of the parameters initially adopted in Table 1 . These new values take into account the continental run-off of freshwater input to the Baltic and serve as a basis for subsequent calculations (Fig. 6, a to d):

Baltic:

SalinBa=0

${ }^{25} \mathrm{SbBa}=\mathrm{O}$

${ }^{137} \mathrm{CsBa}=128.6$

${ }^{134} \mathrm{CsBa}=31.43$

\subsubsection{APPLICATION LIMITS OF THE MODEL}

The model used in this study is based on a number of assumptions whose validity is only partially justified:

In the first place, the variables used to characterize the four water masses are assumed to be independent, constant with time and homogeneously distributed in the incoming flux. But, even if the isotopic ratios of the radionuclides are well differentiated in each water mass, the supply of radionuclides varies in a random way (Fig. 7), their spatial distribution is non-uniform (Fig. $3 \mathrm{~d}$ ), and the inflow of the different water masses depends upon weather conditions and seasonal variations.

Consequently, the values adopted for each input must represent an average incoming flux and should not take spatio temporal variations into consideration.

In other respects, the measured parameters should display conservative behaviour on the time scale of the hydrodynamic system.

The conservative behaviour of the studied radionu clides is a valid assumption outside the areas with high turbidity. However, radioactive decay causes a variation in radionuclide concentrations with time. This means that half-lives must be long enough to cover the renewal time for the North Sea, which has been estimated at between 1 and 5 years (DJENIDI et al., 1986; ICES, 1983; OTTO, 1983; PRANDLE, 1984). Therefore, the relatively short half-lives of ${ }^{134} \mathrm{Cs}$ and ${ }^{125} \mathrm{Sb}$ (2.2 and $2.77 \mathrm{y}$, respectively) are a drawback:

TABLE 1

Average values of variables in water masses entering the North Sea (radioactivity in Bq. $\mathrm{m}^{-3}$ ).

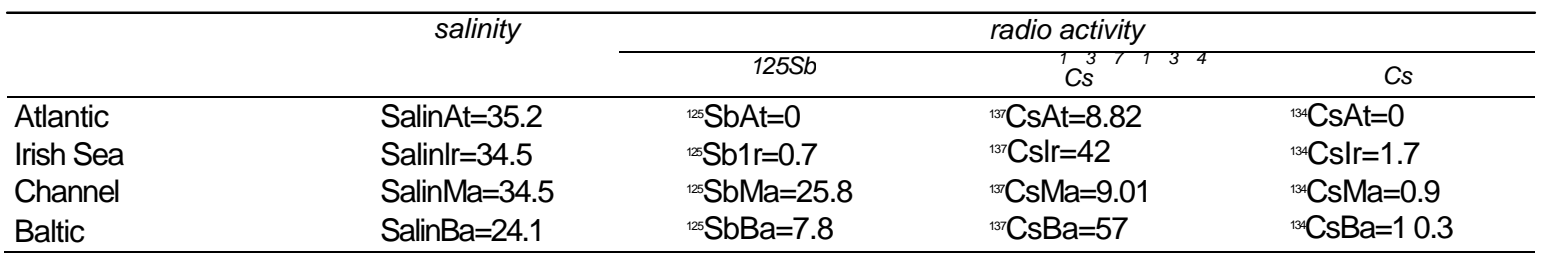



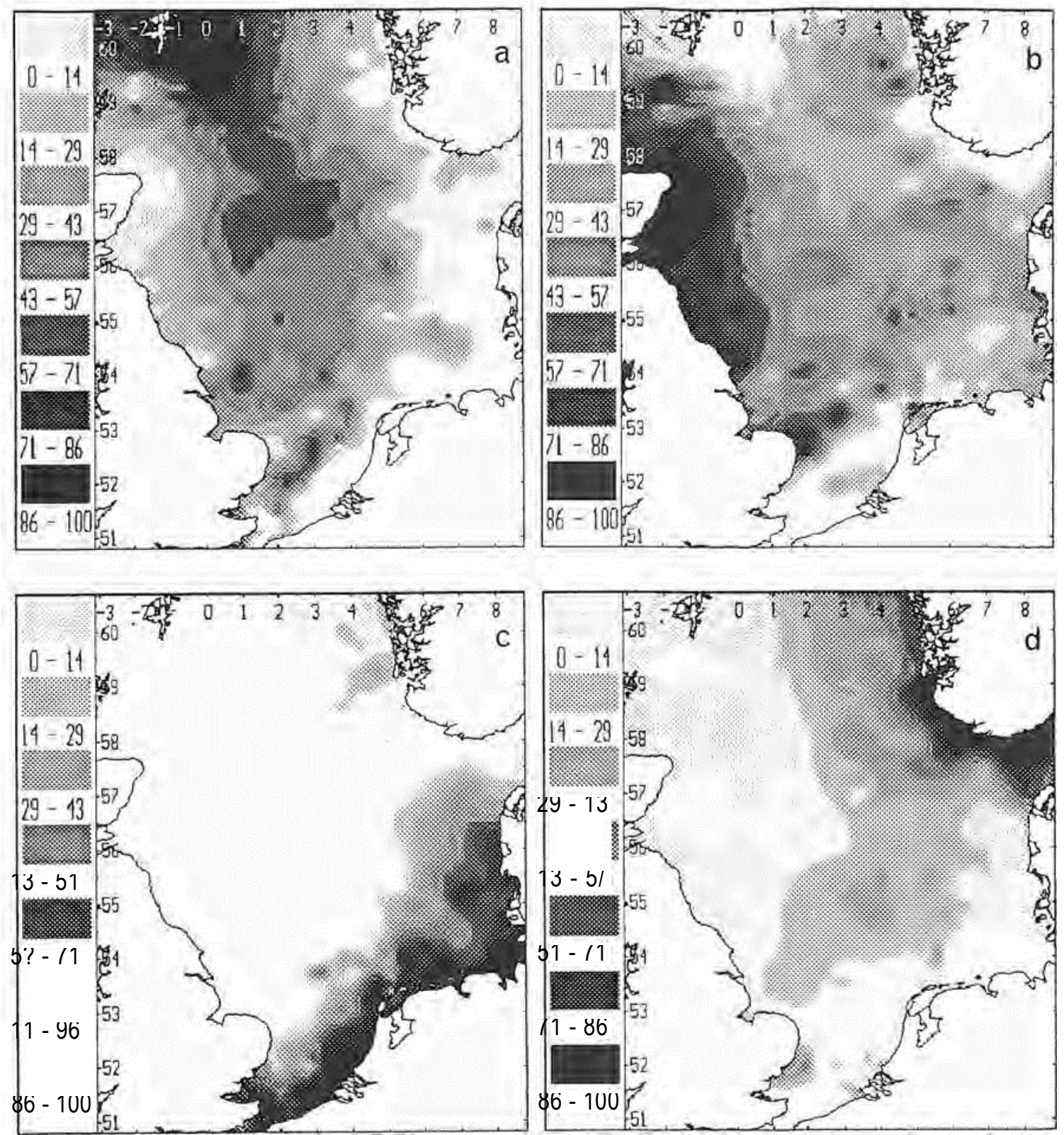

Fig. 4. Modelled distribution of water mass contributions to the North Sea during July 1988. First stage of modelling: the Bal-tic contribution is characterized by the mixing of waters coming through the Skagerrak: (a) the Atlantic in \%, (b) the Irish Sea in \%, (c) the English Channel in \%, (d) the Baltic in \%.

the mixing model would only be valid if their transit times in the North Sea were significantly less than 2 years.

Finally, it is assumed that the inputs of salinity and radionuclides are derived exclusively from the four sources considered in this study.

Because only four variables have been measured, it is theoretically possible to characterize a maximum of four independent inputs. Therefore, contributions from rivers and atmospheric fallout are not taken into account in this model. Nevertheless, since the sum of ail contributions should equal $100 \%$, we can also identify other types of input that are more diffuse in nature (notably, the Chernobyl fallout and various freshwaters).

Despite these important restrictions, and the ana- 
lytical errors which may reach $50 \%$ at the lowest activities, the deviation of the different contribution factors from the data given in Table 1 is always under $10 \%$ when the higher error measurements are taken into account. This suggests a good stability of the model. It is quite remarkable that the sum of all contributions is between 87 and $113 \%$ when only the data presented in 2.3.1. and 2.3.2 are used (cf. sum of contributions: Figs 9a and 9b). Furthermore, the contribution factors for each water-mass are not constrained to be higher than 0 , and results lower than $8 \%$ are observed only for the Atlantic contribution (Fig. 10), along the eastern coasts of the North Sea, corresponding to the anomalously low total of the sum of all contributions.

The system thus appears to be reasonally well described by the model used in this study. Furthermore, the scatter of totals around $100 \%$ can be explained by factors which are easily identified:

- The anomalously high totals (101 to $110 \%$ ) are caused by an over-representation of the influence from the Baltic (Figs 4d and 6d) and quite reasonably appear to be associated with inputs from Chernobyl ( $3 \mathrm{Cs}$ and ${ }^{134} \mathrm{Cs}$ ) that were not taken into account in the calculation of contributions from river waters (Thames, Seine, Rhine, Scheldt, Elbe) or rain water (residual spike seen in the central North Sea and the western Norwegian Channel).

-The anomalously low totals (87-99\%), resulting essentially from the contribution factor of the Atlantic lower than 0 (Fig. 10), are mainly associated with the Channel plume. It is either due to the inhomogeneous labelling of Channel waters at La Hague which enter the North Sea through the Straits of Dover, or to the inflow of freshwaters from major rivers (Rhine, Scheldt, Elbe).

\subsubsection{CORRECTION FOR CONTRIBUTION OF DIFFUSE CHERNOBYL FALLOUT}

The model equations were recalculated after reducing the activities of ${ }^{137} \mathrm{Cs}$ and ${ }^{134} \mathrm{Cs}$ in proportion to the Chernobyl emissions; this was performed in those cases where the sum of contributions exceeded $101 \%$ (overrepresentation of the Baltic). The proportion of ${ }^{34} \mathrm{Cs}$ attributed to the Chernobyl accident - but not coming from the Baltic - was estimated on the basis of a ${ }^{137} \mathrm{Cs} /{ }^{134} \mathrm{Cs}$ ratio of 3.5 , which in turn was derived from the isotopic ratio in May 1986 of 1.86 (MITCHELL \& STEELE, 1988; NIES, 1990). This value characterizes the direct atmospheric fallout from Chernobyl remaining in July 1988 and corrected for radioactive decay.

The criteria used to carry out this third (refinement) calculation were as follows (Fig. 8 a to d):

- data from the second calculation were used for water mass characterization;

-the contributions were constrained to no more than $101 \%$, the surplus being attributed to a direct input of ${ }^{137} \mathrm{Cs}$ and ${ }^{134} \mathrm{Cs}$ (not linked to any other parameter) with a ${ }^{137} \mathrm{CS} /{ }^{134} \mathrm{CS}$ ratio of 3.5 .

The maps (Fig. 8 a to d) show that only the Baltic contribution factor has changed with this third calculation, which means that the anomalously high totals are only associated with Baltic and Chernobyl fallout (the other contributions being nearly unaffected by

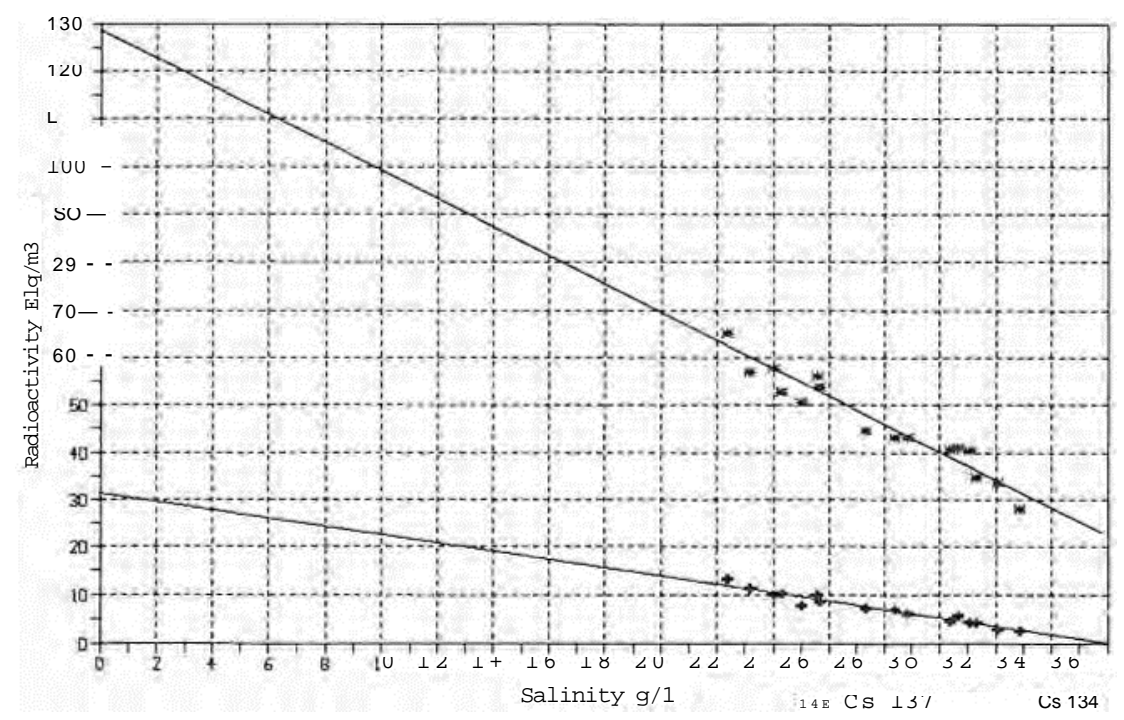

Fig. 5. ${ }^{137} \mathrm{Cs}$ and ${ }^{134} \mathrm{Cs}$ variation as a function of salinity at the entrance to the Baltic; linear extrapolations are used to determine activities of respective freshwater source terms. 

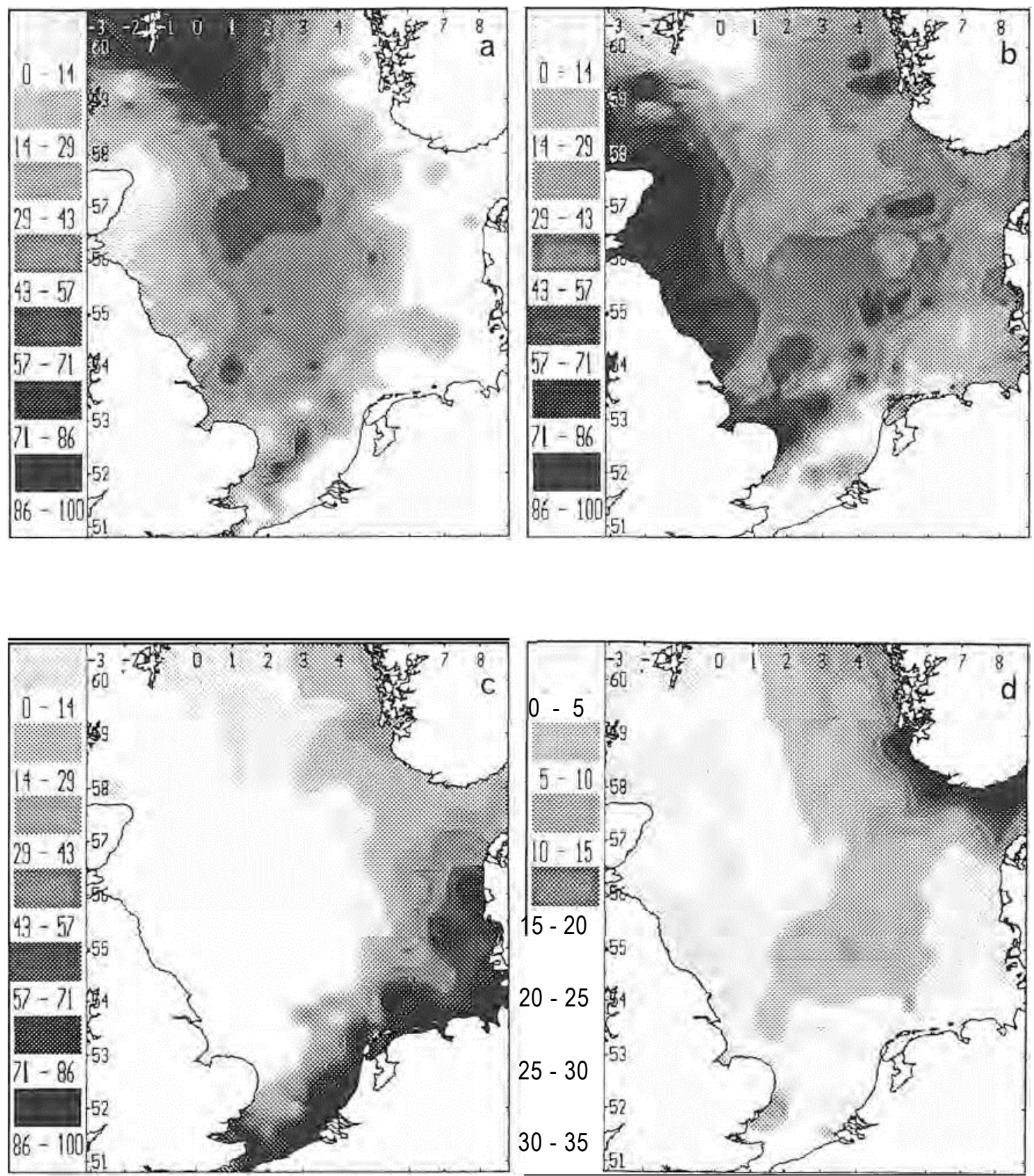

Fig. 6. Contribution factor of inputs to the North Sea during July 1988. Second stage of modelling: Baltic waters are characterized by freshwater source terms as derived from extrapolation: (a) the Atlantic in \%, (b) the Irish Sea in \%, (c) the English Channel in \%, (d) from the Baltic in \%.

this treatment).

The anomalously low totals associated with the English Channel were left uncorrected since the existence of various sources of perturbation (freshwater inflow, inhomogeneity of Channel waters) would render such an attempt highly questionable.

ter inflow, Chernobyl faitout, inhomogeneity of Chan- 


\section{RESULTS AND DISCUSSION}

\subsection{SALINITY, TEMPERATURE AND RADIOACTIVITY MEASUREMENTS}

\subsubsection{SALINITY, TEMPERATURE AND METEOROLOGY (FIGS 2, 10 AND 11)}

The following features are observed:

- a water mass showing a weak salinity gradient from north to south ( $S=35$ to 34.5 ), corresponding to the inflow of oceanic water, extends over about half the area of the North Sea from the Shetlands to as far as the Dogger Bank;

-a tongue of water with the same characteristics at the centre of the English Channel plume;

-a slight drop in salinities around the coastline of England;

-fluviatile inputs along the coast from the Straits of Dover to Denmark, with a minimum inshore salinity of $\mathrm{S}=32$ and a transition zone widening out from south to north $(60 \mathrm{~km}$ at Rotterdam, $200 \mathrm{~km}$ to the west of Denmark).

-an outflow from the Baltic which is characterized by a strong desalination (min $\mathrm{S}=22$ ) in the northern part of the Skagerrak and along the Norwegian coast; this phenomenon is associated with elevated water tem- peratures $\left(>18^{\circ} \mathrm{C}\right)$. A vertical profile carried out in the middle of the Skagerrak shows that, beneath $30 \mathrm{~m}$ depth, the temperature is only 5 to $6^{\circ} \mathrm{C}$ and the salinity fluctuates between $\mathrm{S}=34.3$ and 35 .

Significant variations were observed between the outward and return legs of the cruise within the Skagerrak, where an outflow of brackish water near the surface was recorded from 18 July 1988 onwards (cf. Fig. 2b). This plume was picked up once again from 21 to 24 July, with a southwesterly displacement of $180 \mathrm{~km}$ taking place in the $\mathrm{S}=33$ isohaline over a period of ten days (cf. Fig. 2c). These temperature distribution maps (Figs 2d and 2f) reveal an association between this plume and warmer waters (17 to $18.5^{\circ} \mathrm{C}$ ) which appear to have formed due to an intense heatwave that affected Sweden and Norway in the month preceding the cruise.

Wind observations for this period may explain this phenomenon (Fig. 10); a moderate to strong southwesterly wind persisted from the beginning of the cruise up to 11 July. On 14 and 15 July, a depression centred off the western coast of Den mark brought about an anti-clockwise airflow over Denmark. After this, the southwesterly current was re-established and continued up until the end of the cruise. The depression appears to have 'flushed out' the water masses previously accumulated in the Skagerrak, causing a rapid overflow in the form of a surface

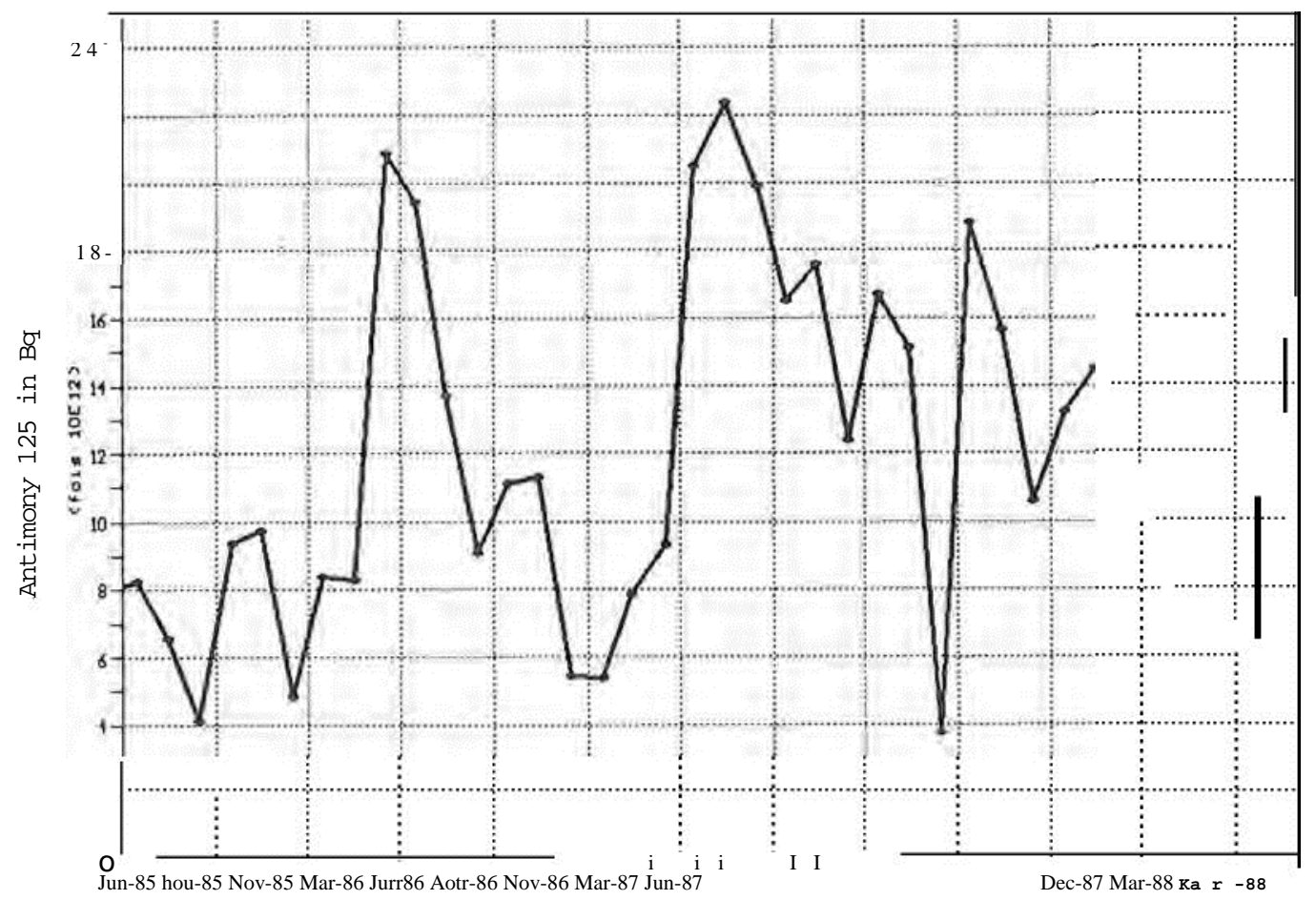

Time in months

Fig. 7. The monthly discharges of Antimony-125 from La Hague into the English Channel between 1985 and 1988. 

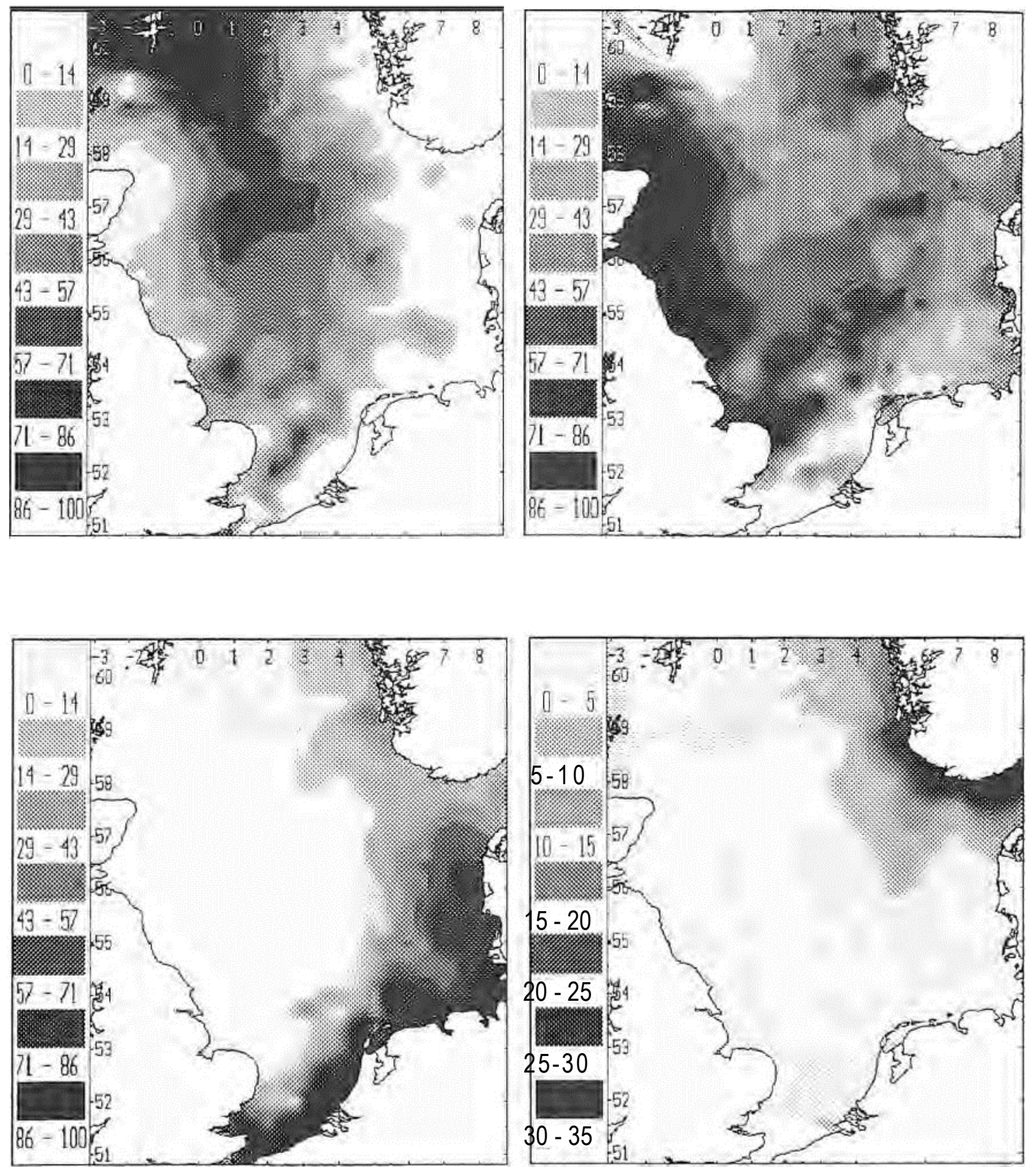

Fig. 8. Contribution factor of inputs to the North Sea during July 1988. Third stage of modelling: the Baltic contribution is characterized by the freshwater influx entering the North Sea through the Skagerrak; and, the contribution of ${ }^{137} \mathrm{Cs}$ and ${ }^{134} \mathrm{Cs}$ derived directly from Chernobyl fallout has been extracted: (a) the Atlantic in \%, (b) the Irish Sea in \%, (c) the English Channel in \%, (d) the Baltic in \%.

sheet towards the North Sea. MORK (1991) has observed between waters coming from the English ascribed the rapid response of Norwegian circulation Channel and waters coming from the central North to wind forces on the scale of the entire North Sea.

Sea; there is a particularly large salinity gradient

Elsewhere, to the west of Denmark ( $A$ and B in Fig. between the coast and the open sea.

$2 \mathrm{a}$ and $\mathrm{C}$ ), a disturbed transition zone can be

Recordings taken along the ship's track show the 
Percentage contribution of inputs from the Atlantic, Irish Sea, English Channel and Baltic into the North Sea during 1988: A tracer-based evaluation using artificial radionuclides, Bailly du Bois et al.
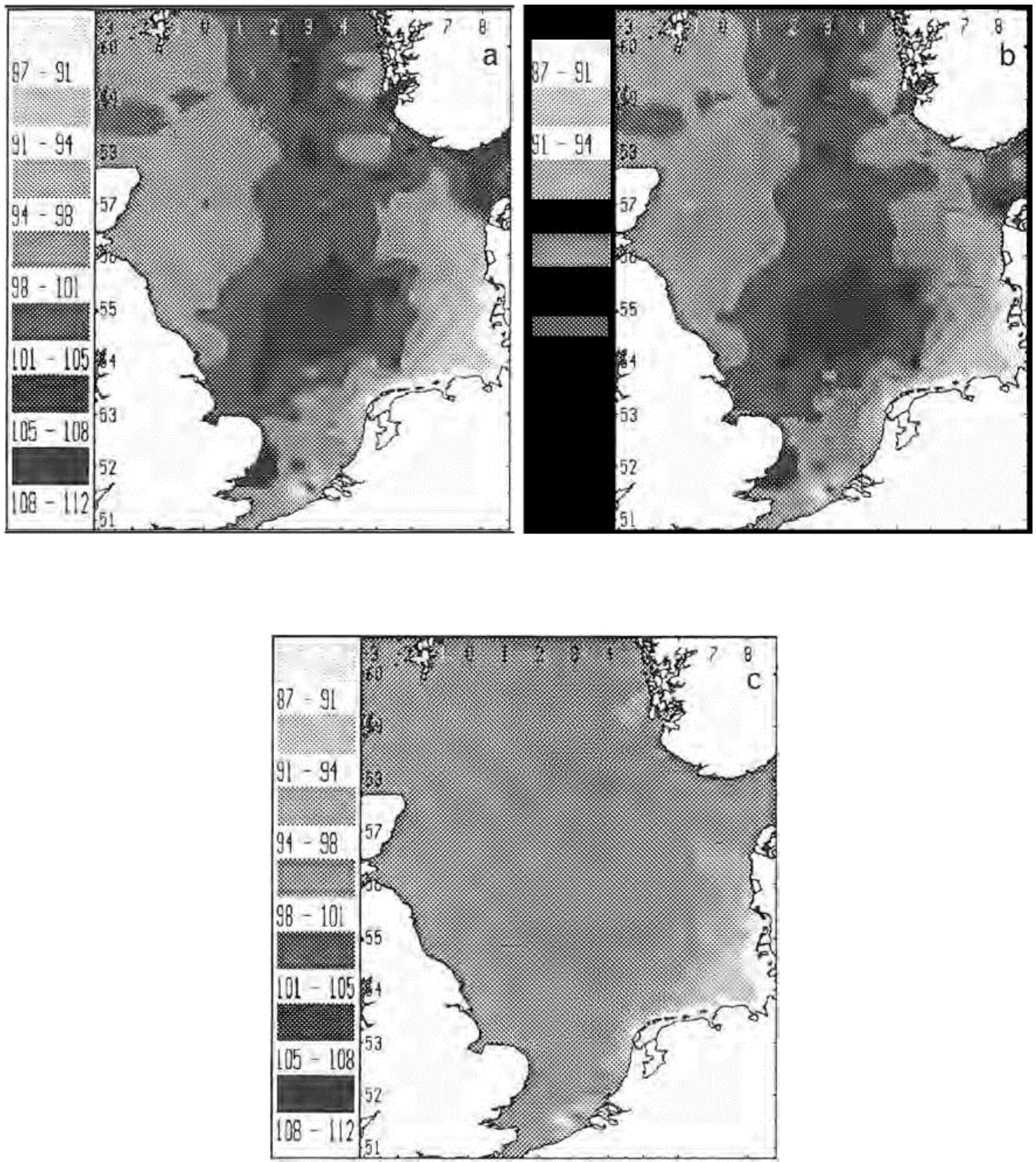

Fig. 9. Summation of contributions (in \%) from four water mass inputs, using three different model calculation methods: (a) first modelling method, (b) second modelling method, (c) third modelling method.

following features (Figs 12a and 12b):

-repetitive structures with alternations of more or less salty water;

-homogeneous temperatures;

- similarities in the sequence of structures observed, with a certain symmetry on either side of an axis.
This suggests that there are vortices which cause mixing between the open sea and coastal waters. Such a hypothesis would be in agreement with the existence of fairly large amplitude vortices, as described in this region by BOHNECKE (1922). The size of the observed structures varies from -30 to 
12 Percentage contribution of inputs from the Atlantic, Irish Sea, English Channel and Baltic into the North Sea during 1988: A tracer-based evaluation using artificial radionuclides, Bailly du Bois et al.

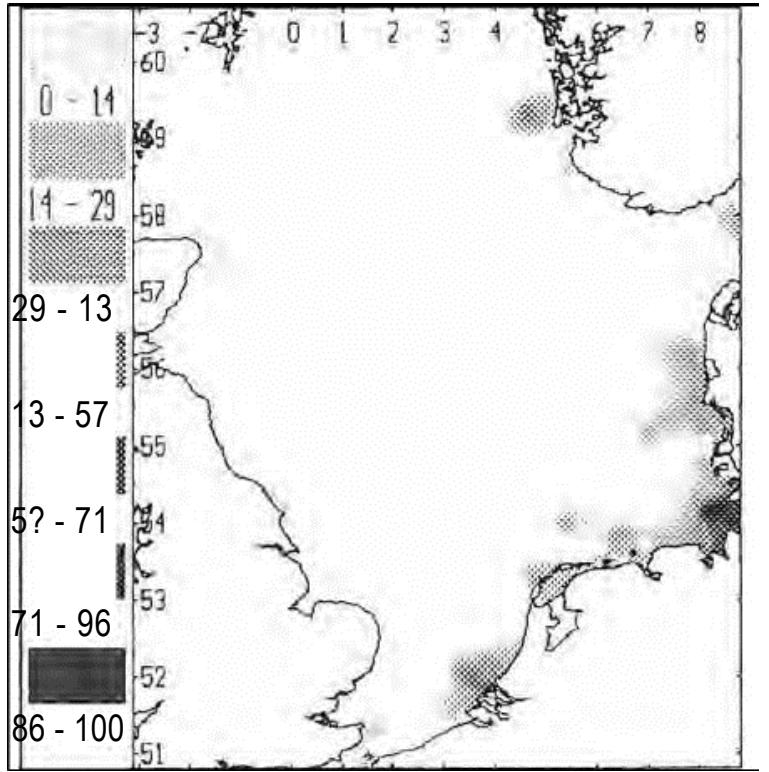

Fig. 10. Contribution factor lower than 0 of waters coming from the Atlantic in \%, third stage of modelling.

$-90 \mathrm{~km}$, with three of them being recognized along latitude $56^{\circ} \mathrm{N}$; these structures suggest the existence of zones favourable for vortex formation, as indicated by NIHOUL (1980).

This type of structure, which was not observed in subsequent cruises, seems to be associated with a particular set of weather conditions (in this case, strong southwesterly winds that persisted nearly throughout the cruise). Nevertheless, such weather phenomena may play an important role in the dispersion mechanisms affecting dissolved elements.

\subsubsection{ANTIMONY-125} (FIG. 3A)

The presence of ${ }^{125} \mathrm{Sb}$ is a specific feature of waters released from the reprocessing plant at La Hague; this tracer is associated with the English Channel plume as it passes along the southeastern and eastern coasts of the North Sea, showing that Channel waters account for more than $70 \%$ of the supply in the nearshore zone as far east as the German Bight. Activities decrease gradually from the Straits of Dover $\left(30 \mathrm{~Bq}-\mathrm{m}^{-3}\right)$ to the Skagerrak $(11 \mathrm{~Bq}-$ $\mathrm{m}^{-3}$ ), with progressive dilution of the English Channel plume as it penetrates offshore. The distribution of ${ }^{125} \mathrm{Sb}$ is fairly irregular as far as the Skagerrak in

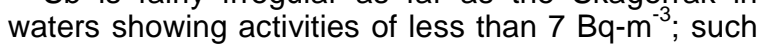
variations may be explained as follows: -by local weather conditions causing transient intrusions of offshore water, which are less pronounced in coastal waters of the English Channel and North Sea; -by fluctuations in releases from La Hague.

Beyond the Skagerrak, the labelling is far more homogeneous. Activities are always higher near the Norwegian coast, with a regular gradient (11 to $2 \mathrm{~Bq}-$ $\mathrm{m}^{-3}$ ) towards the open sea. (Values are detectable as far as $160 \mathrm{~km}$ away from the Norwegian coast, halfway to the Shetlands.)

\subsubsection{CAESIUM-137 AND CAESIUM-134 (FIGS 3B AND 3C)}

The distribution of ${ }^{137} \mathrm{Cs}$ (half-life: $30 \mathrm{y}$ ) during the Tramanor-I cruise made it possible to monitor the movements of the principal water masses in the North Sea. The use of ${ }^{134} \mathrm{Cs}$ or the ${ }^{137} \mathrm{CS} /{ }^{134} \mathrm{CS}$ ratio $(\mathrm{R})$ enabled a distinction to be made between material from atmospheric nuclear tests or industrial releases $(R>11)$ on the one hand, and material attributed to the Chernobyl accident on the other $(R=3.38$ to 3.61 in July 1988).

The following inputs may be recognized:

-Atlantic waters near the Shetlands $\left({ }^{137} \mathrm{Cs}=7\right.$ to 11 $\mathrm{Bq} \cdot \mathrm{m}^{-3}, \mathrm{R}>30$ ) show little influence from Chernobyl fallout, and a contribution from Sellafield releases of

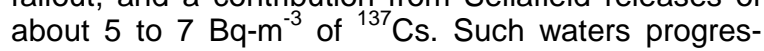
sively replenish other waters in the central North Sea which are more strongly affected by these contributions $\left({ }^{137} \mathrm{Cs}=10\right.$ to $45 \mathrm{~Bq}-\mathrm{m}^{-3}, \mathrm{R}=10$ to 35$)$.

-Atlantic waters strongly labelled by releases from the Sellafield reprocessing plant into the Irish Sea $\left({ }^{137} \mathrm{Cs}=30\right.$ to $\left.50 \mathrm{~Bq}-\mathrm{m}^{-3}, \mathrm{R}>20\right)$ travel down the coastline of Eng land from north to south and are gradually diluted into the previously mentioned water masses. -Waters coming from the English Channel, less strongly affected by releases from the nuclear fuel reprocessing plant at La Hague $\left({ }^{137} \mathrm{Cs}=3\right.$ to $11 \mathrm{~Bq}-\mathrm{m}$ $3, \mathrm{R}>20$ ), are clearly apparent along the eastern coasts of the North Sea, even though the plume is only weakly labelled with ${ }^{137} \mathrm{Cs}$.

- The estuaries of rivers (Thames, Seine, Rhine, etc.), are affected by the fallout of Chernobyl-derived material onto the catchment areas $\left({ }^{137} \mathrm{Cs}=20\right.$ to 40 $\left.B q-m^{-3}, R<8\right)$.

- The entrance to the Baltic itself is also characterized by the Chernobyl spike ${ }^{1{ }^{17}} \mathrm{Cs}=50$ to $70 \mathrm{~Bq}-\mathrm{m}^{-3}$, $\mathrm{R}<8$ ), which can be followed up through the Norwegian Channel as far as the outlet of the North Sea.

Owing to labelling with ${ }^{137} \mathrm{Cs}$ and ${ }^{134} \mathrm{Cs}$, it is possible to visualize - over a distance of $200 \mathrm{~km}$ - the front which delimits the waters leaving the North Sea in an area to the west of Bergen (Norway) (surface water: ${ }^{137} \mathrm{Cs}=15$ to $50 \mathrm{~Bq}-\mathrm{m}^{-3}, 6>\mathrm{R}=6$ to 15$)$.

A marked ${ }^{137} \mathrm{Cs}$ spike is apparent coming from the Sellafield plant, despite a large decrease in the level of releases since 1985. We therefore suppose that significant amounts of Cs from pre-1985 releases 

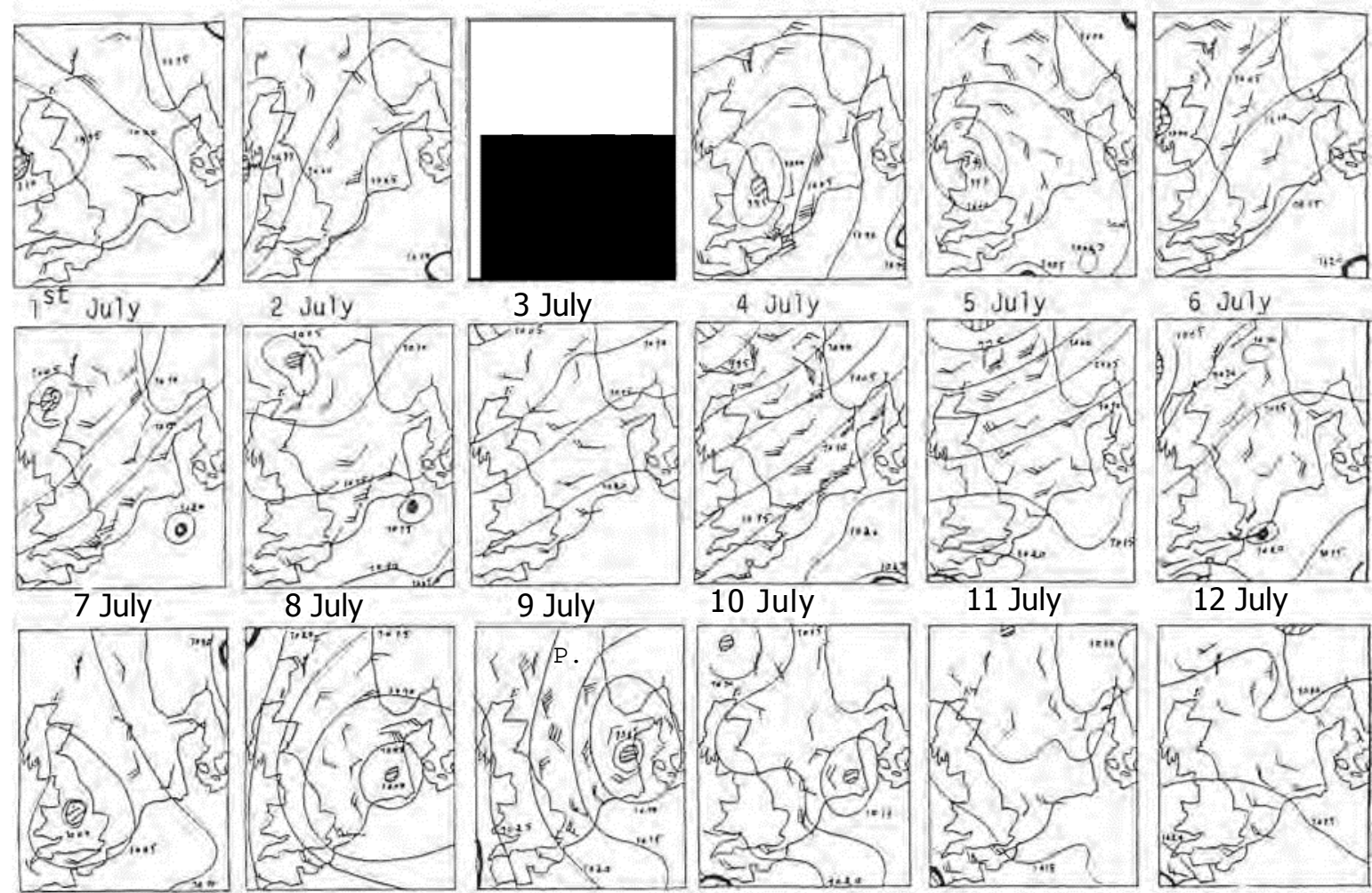

8 July 9 July
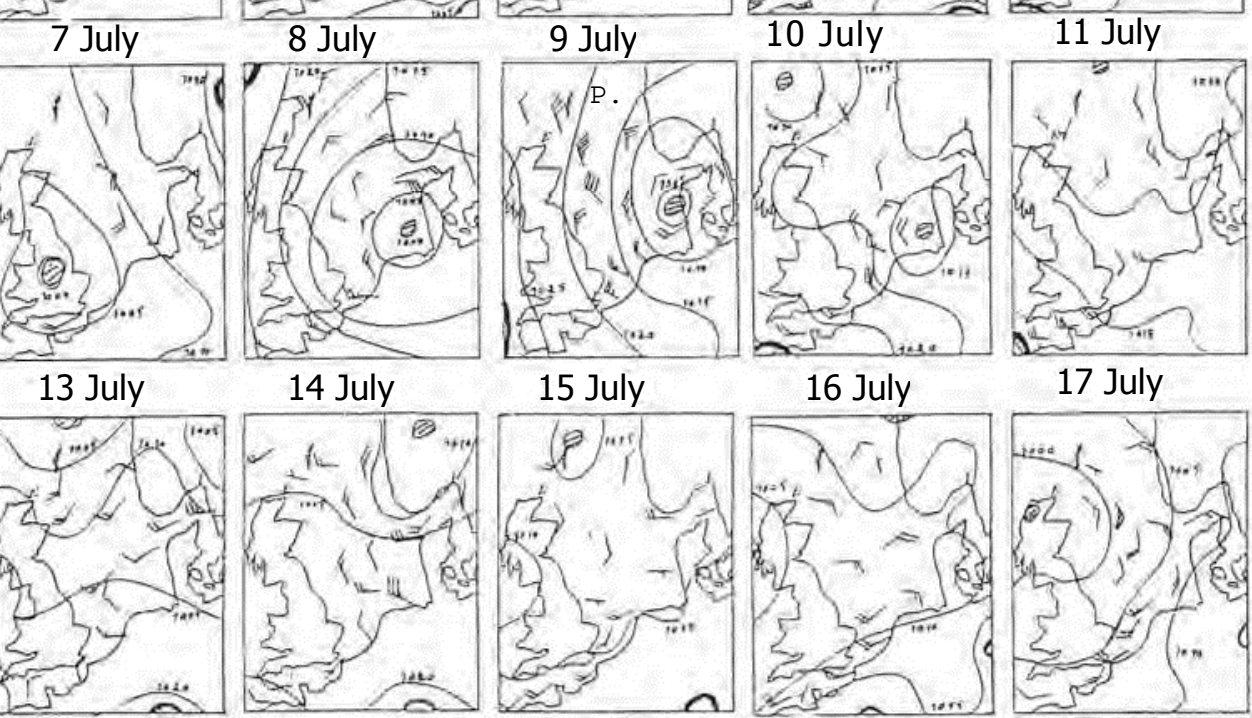

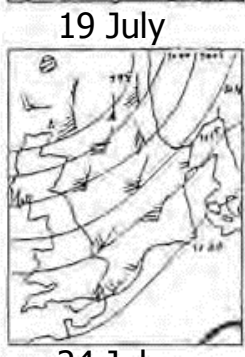

24 July
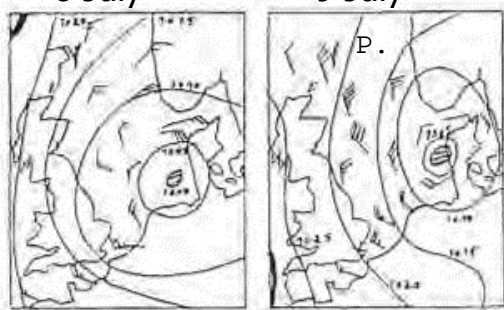

16 July

17 July

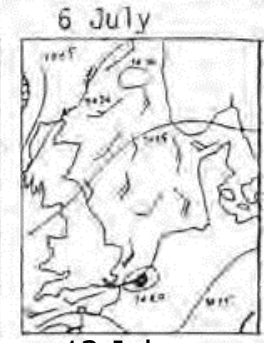

12 July
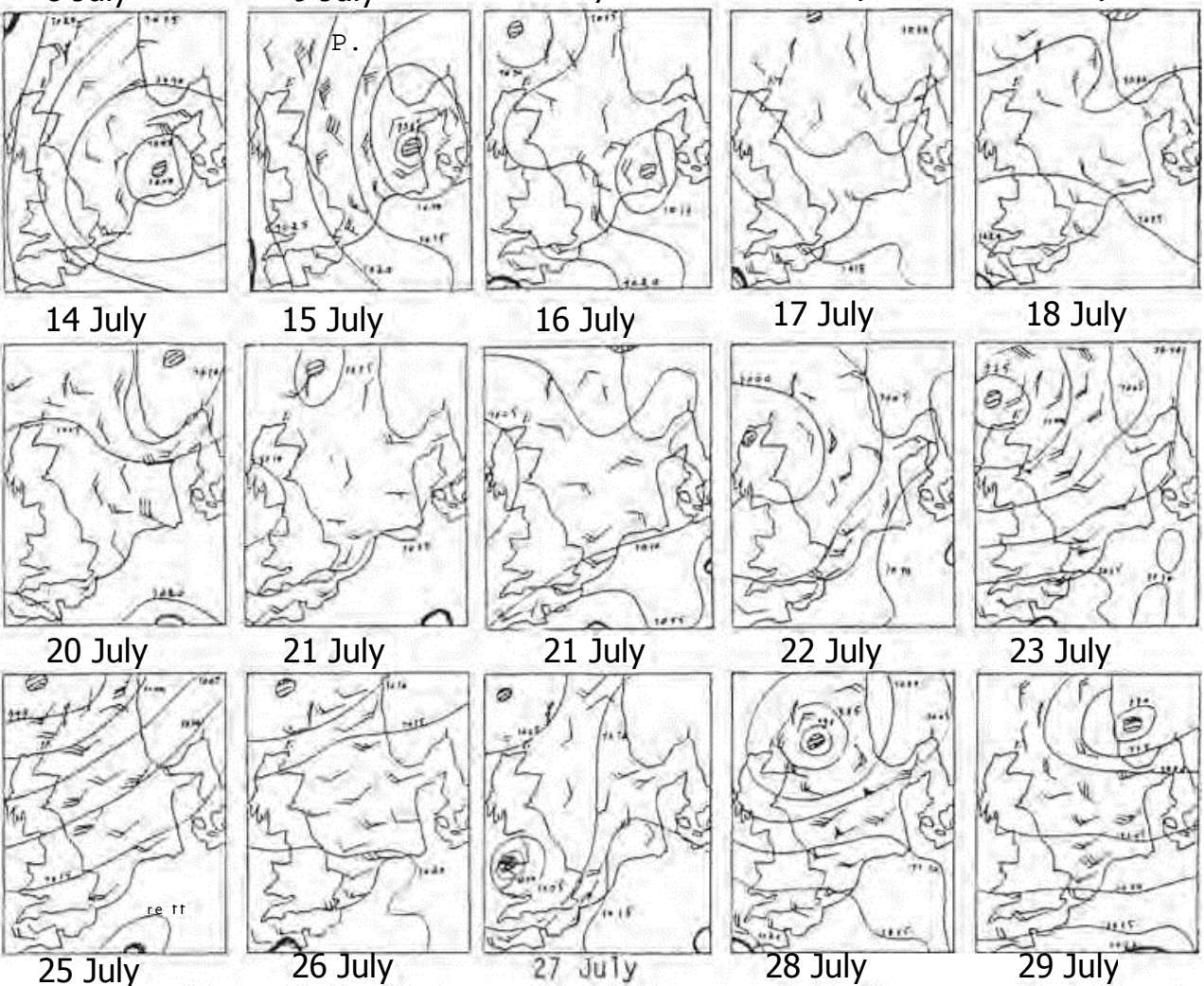

22 July

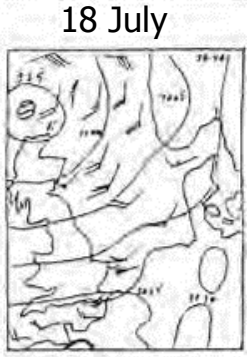

O Depression

$\oslash$ Anticyclone

Fig. 11. Synoptic weather maps showing atmospheric pressure and winds in the North Sea from 1 to 30 July 1988. 
14 Percentage contribution of inputs from the Atlantic, Irish Sea, English Channel and Baltic into the North Sea during 1988: A tracer-based evaluation using artificial radionuclides, Bailly du Bois et al.
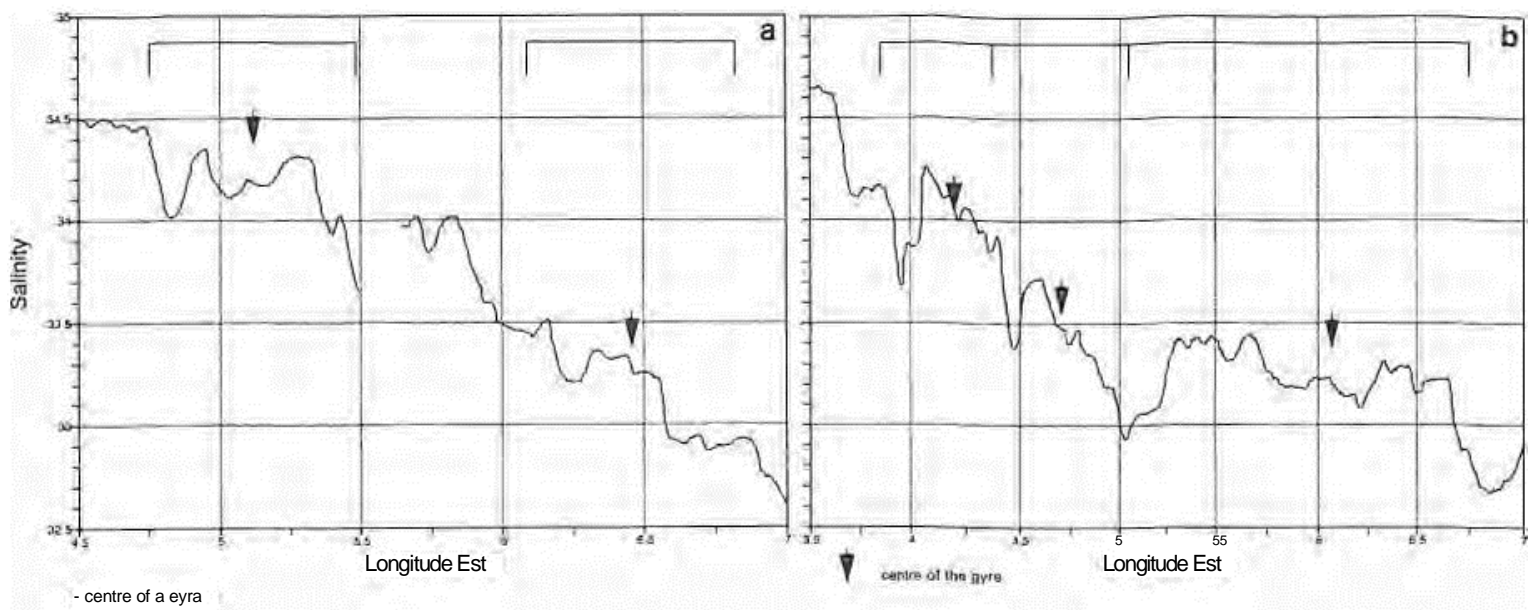

Fig. 12. Salinity profiles in the German Bight during July 1988: (a) along a traverse in zone A, at latitude $55^{\circ} \mathrm{N}$ (see Fig. 2a), and (b) along a traverse in zone B, at latitude $56^{\circ} \mathrm{N}$ (see Fig. 2c).

have accumulated in sediments of the Irish Sea and are now being remobilized (MALCOM, 1991; McCARTNEY et al., 1991).

\subsection{MIXING MODEL RESULTS: THE WATER MASSES}

\subsubsection{ATLANTIC INFLOW (FIGS 4A, 6A, 8A)}

Atlantic waters are predominant in an area from the Shetlands to the middle of the North Sea. Their contribution diminishes towards the coast and becomes practically non-existent along the eastern shores of the North Sea. Waters from the Irish Sea and English Channel form a limit to the propagation of Atlantic waters, confining them to the central North Sea; the outlet is shifted to the west of the Norwegian Channel.

There is an important contribution of Atlantic waters near the western edge of the English Channel plume, particularly in the middle of the southern North Sea between Lowestoft and the Dutch coast as well as in the Gulf of Hamburg. These anomalies are probably linked to the inhomogeneous labelling (due to releases from La Hague) of English Channel waters passing through the Straits of Dover; this plume is less affected by releases from La Hague in a zone near the English coast. Such water masses can reasonably be identified as coming from the Atlantic in view of their measured parameters. The correction of such anomalies would be entirely hypothetical, especially since they depend on fluctuations in the levels of releases from La Hague. Thus, it is preferable to refer to the distribution of Irish Sea waters in order to define the limit of penetration of the English Channel plume.

\subsubsection{THE IRISH SEA IN FLOW (FIGS 4B, 6B, 8B)}

Waters coming from the Irish Sea pass around the north of Scotland before turning southward to travel along the eastern seaboard of England (KAUTSKY, 1973). The Irish Sea inflow is then progressively diluted as it mixes with Atlantic waters in the middle of the North Sea until its contribution is reduced to $30 \%$. At the latitude of Lowestoft, the Irish Sea inflow displays a minor incursion as far as the Dutch coast off Rotterdam. It then turns towards the NE, showing a more irregular distribution as it mixes with the English Channel plume. A patchy type distribution becomes more apparent in the Norwegian Channel, suggesting that the displacement of water masses is discontinuous. In this region, a laminar structure is observed parallel to the coastline, but the water masses are also strongly influenced by transient phenomena (meteorological conditions, vortices as proposed in section 3.1.1).

\subsubsection{THE ENGLISH CHANNEL INFLOW (FIGS 4C, 6C, 8C)}

English Channel waters predominate in a zone extending along the coast from the Straits of Dover as far as Denmark, with a contribution ranging from 90 to $60 \%$. The plume widens out from south to north, as it mixes with Irish Sea waters, and important fluctuations are observed. The influence of the English Channel plume stays more pronounced near the Danish and Norwegian coasts, and it appears that mixing is not completely homogeneous even at the outlet of the North Sea. Here, the contribution from the English Channel still represents 5 to $33 \%$ of surface waters. 

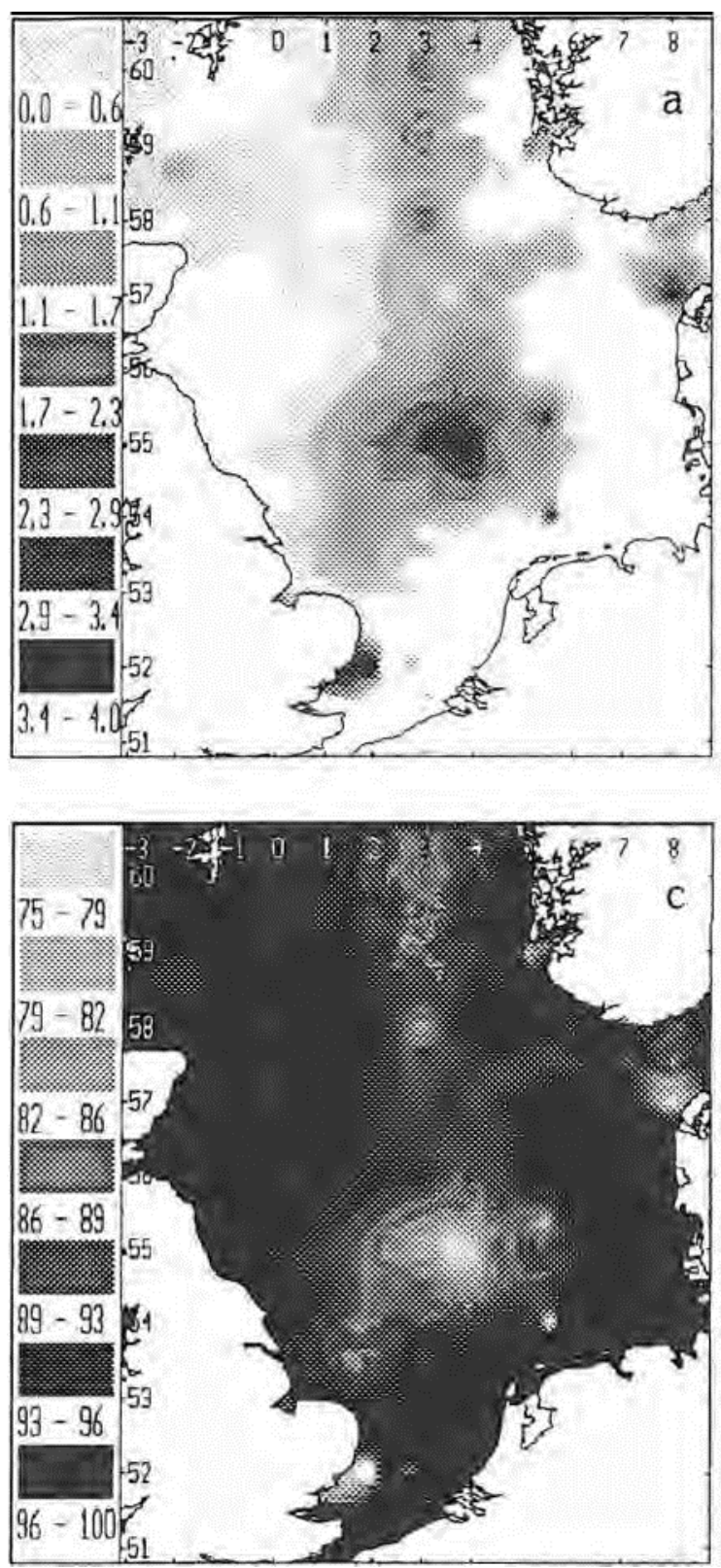

\subsubsection{THE BALTIC INFLOW (MIXING OF FRESH AND MARINE WATERS) (FIGS 4D, 6D AND 8D)}

At the surface, waters leaving the Baltic occupy the northern half of the Skagerrak, then travel northward along the Norwegian coast; the plume shows a highly irregular pattern towards the west, which is probably due to meteorological conditions (see section 3.1.1.). The influence of Chernobyl fallout, identified as coming from the Baltic, could not be entirely removed

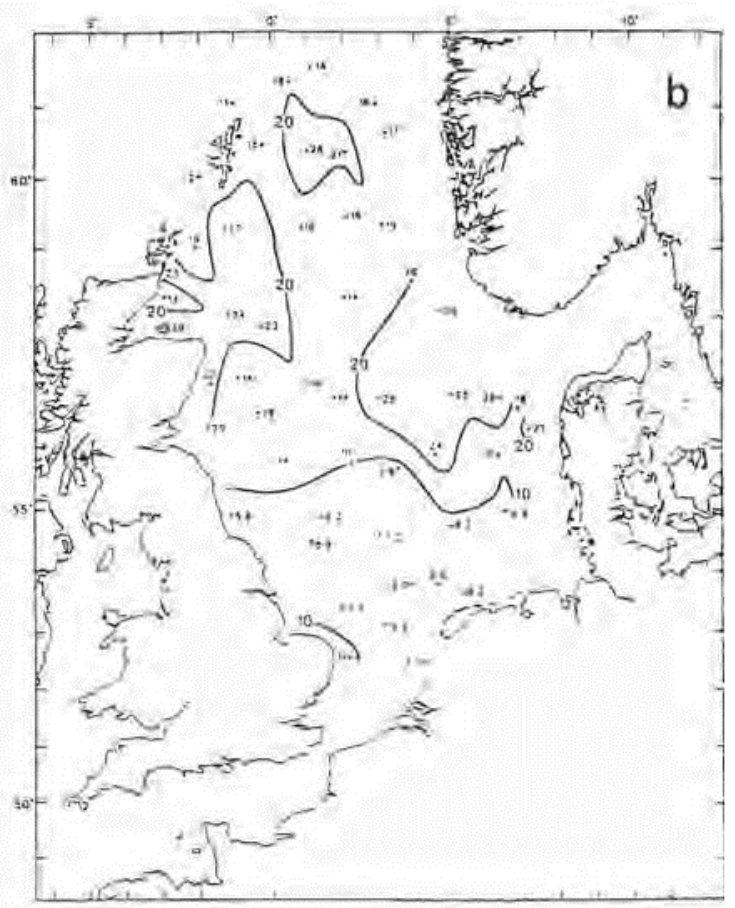

Fig. 13. Evaluation of the degree of renewal for waters in the North Sea between 1986 and 1988: (a) residual ${ }^{134} \mathrm{Cs}$ contribution during July 1988 due to direct fallout from the Chernobyl accident, (b) seawater ${ }^{134} \mathrm{Cs}$ activity in Bq. $\mathrm{m}^{-3}$ during August-September 1986 (alter MITCHELL \& STEELE, 1988), and (c) estimate of degree of renewal (in \%) for waters in the North Sea between July 1986 and July 1988.

from the whole North Sea data set, thus accounting for a diffuse residual contribution of $<5 \%$.

\subsubsection{CHERNOBYL CONTRIBUTIONS IN RELATION TO RENEWAL OF NORTH SEA WATERS (FIG. 13, A TO C)}

Using the data presented in section 2.3.4., the diffuse labelling associated with atmospheric fallout from the Chernobyl accident becomes clearly visible in the central North Sea (Fig. 13a: cf. distribution of ${ }^{134} \mathrm{Cs}$ associated).

Since the Chernobyl fallout was fairly homogeneous in 1986 (cf. Fig. $13 \mathrm{~b}$ showing ${ }^{34} \mathrm{Cs}$ during August 1986; MITCHELL \& STEELE, 1988), this spike enables us to visualize the zones with the lowest renewal rates. Furthermore, some indications can be obtained on the residence times of water masses in the North Sea. Thus, by using the mean activities calculated by these authors, it is possible to estimate the rate of renewal for the North Sea over a period of two years (Fig. 13c). This calculation is fairly approximate since it assumes, on the one hand, a pertect homogenization of the spike in 1986 and, on the other hand, a 
16 Percentage contribution of inputs from the Atlantic, Irish Sea, English Channel and Baltic into the North Sea durina 1988: A tracer-based evaluation usina artificial radionuclides. Baillv du Bois et al.

constant amount of labelling in the other water masses during the period concerned. Nevertheless, this approach allows us to fix an order of magnitude.

Renewal of the peripheral zones of the North Sea appears to be complete in a period of two years, while more than $75 \%$ of the entire volume is replenished in the same time span. The oldest waters are situated in the central sector around latitude $55^{\circ} \mathrm{N}$, showing an extension to the north between the Norwegian Channel and the Atlantic water inflow at longitude $3^{\circ} \mathrm{E}$.

However, these results refer only to surface waters and are not representative of the entire water volume. The calculated renewal rates in this study are higher than previously published estimates (DJENIDI et al., 1986; ICES, 1983; OTTO, 1983; PRANDLE, 1984); this is compatible with the great consistency of results obtained in the present calculated model of water mass distribution, where only the data of the entrances during the cruise are taken into account.

An inspection of previously obtained data on the distribution of radionuclides in this area reveals that the mean activities of ${ }^{137} \mathrm{Cs}$ at the entrances of the North Sea exhibit relatively little variation after October 1987 (NIES, 1990). By contrast, the data collected during 1986 show activity levels which are significantly higher for the Irish Sea, English Channel and Baltic inflows.

In the same way, releases of ${ }^{125} \mathrm{Sb}$ from La Hague show generally little variation of the average level between December 1986 and February 1988 (Fig. 7); on the basis of this tracer, a transit time of about six months can be estimated for waters travelling between La Hague and the Straits of Dover. Using the same tracer, a residence time of 13 months may be estimated for Channel waters in the near-surface zone of the North Sea. Furthermore, this duration is in agreement with the estimates of GUÉGUÉNIAT et al. (1992), who give values based on the dilution of ${ }^{253} 3 \mathrm{~b}$ in waters affected by releases from La Hague.

In the next phase of research, transit times are to be further refined, using quantitative analyses of the amounts of radioactivity present in seawater samples, and taking into account the various cruises carried out between 1988 and 1991.

Finally, two anomalies can be observed - in the NE part of the Thames estuary and NW of Denmark which are associated with excess ${ }^{134} \mathrm{Cs}$ and ${ }^{137} \mathrm{Cs}$ activities not easily related to diffuse fallout onto the North Sea during 1986. These anomalies could be explained by intense and transient labelling of river waters due to heavy rainfall in the catchment areas.

\section{CONCLUSIONS}

The Tramanor-I cruise, carried out in the North Sea during July 1988, has enabled the construction of regional maps showing the distribution of salinity and temperature, as well as the activities of ${ }^{125} \mathrm{Sb},{ }^{137} \mathrm{Cs}$ and ${ }^{134} \mathrm{Cs}$. The highest radiocaesium activities were observed at the outlet of the Baltic $\left(71\right.$ Bq. $\cdot n^{-3}$ for ${ }^{137} \mathrm{Cs}$ and 13 for ${ }^{134} \mathrm{Cs}$ ); this input is associated with fallout from the Chernobyl accident. The highest activities for ${ }^{125} 5 \mathrm{~b}$ were recorded in the Straits of Dover (41 Bq.m $\left.{ }^{3}\right)$. Around the outlet to the Norwegian Channel, activities for ${ }^{137} \mathrm{Cs},{ }^{134} \mathrm{CS}$ and ${ }^{125} \mathrm{Sb}$ were 40,4 and 5 Bq. $\mathrm{m}^{-3}$, respectively.

Furthermore, an inspection of the raw data (see salinity profiles), as well as the distribution patterns obtained in this study, underlines the important role of meteorological fluctuations in the movement of surface waters throughout the North Sea.

In the present study, the distribution of salinity and various artificial radionuclides in the North Sea (as measured in July 1988) is interpreted in terms of the inflow of four contributory water masses coming from the English Channel, the Baltic, the Atlantic and the Irish Sea; each of these contributions can be identified by its specific characteristics.

The solving of a set of four linear equations at all points of the data grid forms the basis for Figs 4, 6 and 8 , which show the contribution factors attributed to the four influxes.

The calculated contribution pattern shown on these maps provides valuable information on the cumulated effects of displacement of major water masses at a given moment in time over the entire North Sea.

Despite the uncertainties in the measurements and the approximate nature of the hypotheses, the sums of the calculated contributions fall in the range of 87 to $113 \%$. The deviations from $100 \%$ can be explained in terms of inputs that have not been taken into account in the calculation (freshwater inflows and diffuse radioactive sources). These anomalies were partly incorporated into the modelling, thus allowing extraction of the component attributable to fallout from the Chernobyl accident (Fig. 13a). A comparison of these model results and previously obtained data shown in Fig 13b serves to estimate the rate of renewal in the various zones of the North Sea. In all zones renewal is found to be greater than $75 \%$ over two years (Fig. 13c), which is a much shorter transit time of surface waters of the North Sea than previously estimated (DJENIDI et al., 1986; ICES, 1983; OTTO, 1983; PRANDLE, 1984).

The characterization in the present study of water masses as a function of their various engins may lend some support to the hydrodynamic models which have been proposed for the North Sea. It may also help explain the transport of nutrients and pollutants as well as heat transfer mechanisms in the North Sea.

However, the present data do not include any quantitative estimate of fluxes or transit times; such estimates will form the object of further research based not only on the results of several cruises that have already been carried out but also data from greater water depths. 
Percentage contribution of inputs from the Atlantic, Irish Sea, English Channel and Baltic into the North Sea during 1988: A tracer-based evaluation using artificial radionuclides, Bailly du Bois et al. 17

Acknowledgements-We are indebted to all those who supported our work by taking samples at sea or assisting our work on the research vessels, especially the crew of RV 'Cryos'.

\section{REFERENCES}

AARKROG, A., H. DAHLGAARD, L. HALLSTADIUS, $H$. HANSEN \& E. HOLM, 1983. Radiocaesium from Sellafield effluents in Greenland waters.-Nature 304: 49-51.

AARKROG, A., S. BOELSKIFTE, H. DAHLGAARD, S. DUNIEC, L. HALLSTADIUS, E. HOLM \& J.N. SMITH, 1987.Technecium-99 and cesium-134 as long distance tracers in Arctic waters.-Estuar. coast. Shelf Sci. 24: 637647.

BOHNECKE, G., 1922. Salzgehalt und Strômungen der Nordsee.-Verôff. Inst. Meeresk. Univ. Berlin N.F. A, 10, 34 B. F. A. Georg.-naturwiss. R. M. 10:1-34.

DJENIDI, S., J.C.J. NIHOUL \& A. GARNIER, 1986. Modèle mathématique du transport des radionucléides sur le plateau continental nord-européen. Radionucleides: a tool for oceanography. Elsevier Applied Science, London-New York.

GANDON, R. \& P. GUÉGUÉNIAT, 1992. Preconcentration of seawater samples for gamma-ray spectrometric analysis.Radiochimica Acta 57: 159- 164.

GUÉGUENIAT, R, R. GANDON, Y. BARON, J.C. SALOMON, J. PENTREATH, J.M. BRILINSKY \& L. $\mathrm{CABIOCH}, 1988$. Utilisation de radionucléides artificiels $\left({ }^{125} \mathrm{Sb}-137 \mathrm{c}_{\mathrm{s}}-134 \mathrm{c}_{\mathrm{s}}\right)$ pour l'observation des déplacements des masses d'eau dans la Manche. Radionuclides: a tool for oceanography. Elsevier Applied Science, LondonNew York: 260- 270.

GUÉGUÉNIAT, P., P. BAILLY du BOIS, R. GANDON, J.C. SALOMON, R. LEON \& Y. BARON, in press. ${ }^{125} \mathrm{Sb}$, an important conservative tracer in the marine environment: application to the study (1987 1989) of the penetration of the Channel waters in the North Sea.-Estuar. coast. Shelf Sci. in press.

ICES, 1970. Monthly means of surface temperature and salinity for areas of the North sea and North-eastern North Atlantic. Copenhagen.

-, 1983. Flushing times of the North Sea. Int. Council for the Exploration of the Sea. Copenhagen, August1983, Report 123.

JEFFERIES, D.F. \& A.K. STEELE, 1989. Observed and predicted concentrations of caesium 137 in seawater of the Irish Sea 1970-1985.-J. Environ. Radioactivity 10:173- 189.

KAUTSKY, H., 1973. The distribution of the radionuclide caesium 137 as an indicator for the North Sea watermass transport.-Dt. hydrogr. Z. Erg.-H.B. 26: 241-246.

,- 1976 . The caesium-137 content in the water of the
North Sea during the years 1969 to 1975.-Dt. hydrogr. Z. Erg. -H.B. 29: 217-221.

-, 1988. Artificiel radioactivity in the North Sea and the northern north Atlantic during the years 1977 to 1986. IAEA, Hamburg 1988: 71-102.

MALCOLM, S.J., 1991. Radiocaesium in north-east Irish Sea sediment: Interstitiel water chemistry. Radionuclides in the Study of the Marine Processes. Elsevier Applied Science, London-New York: 1-378.

McCARTNEY, M., D.C. DENOON, P.J. KERSHAW \& D.S. WOODHEAD, 1991. Artificiel radionuclides in the surface sediment of the Irish Sea. Radionuclides in the Study of the Marine Processes Elsevier Applied Science, LondonNew York: 1-377.

MITCHELL, N.T. \& A.K. STEELE, 1988. The marine impact of caesium-134 and -137 from the Chernobyl reactor accident.-J. Environ. Radioactivity 6:163-175.

MORK, M., 1981. Circulation phenomena and frontal dynamics of the Norwegian coastal current.-Phil. Trans. R. Soc. Lond. A 302: 635-647.

NIES, H., 1990. The contamination of the North Sea by artificiel radionuclides during the year 1987.-J. Environ. Radioactivity 11: 55-70.

NIES, H. \& Ch. WEDEKIND, 1988. The contamination of the North Sea and Baltic Sea by the Chernobyl fallout. Radionuclides: a tool for oceanography. Elsevier Applied Science, London-New York: 227-239.

NIHOUL, J.C.J., 1980. Residual circulation, long waves and mesoscale eddies in the North Sea.-Oceanol. Acta 3: 309-316.

OTTO, L., 1983. Currents and water balance in the North Sea. North Sea Dynamics. Springer-Verlag, Berlin Heidelberg: 26-43.

PRANDLE, D., 1978. Residual flows and elevations in the southern North Sea.-Proc. R. Soc. Lond. A 359: 189- 228.

-, 1984. A modelling study of the mixing of ${ }^{137} \mathrm{Cs}$ in the seas of the European continental shelf.-Phil. Trans. Roy. Soc. London A310: 407-436.

TAYLOR, A.H. \& J.A. STEPHENS, 1983. Seasonal year-to-year changes in the temperatures of the English Channel and the southern North Sea 19611976: a budget.- Oceanol. Acta 6: 63-72.

TAYLOR, A.H., P.C. REID, T.J. MARSH, J.A. STEPHENS \& T.D. JONAS, 1983. Year-to-year changes in the salinity of the southern North Sea 1948-1973: a budget. North Sea dynamics. Springer-Verlag Berlin Heidelberg: 199-219.

VAN PAGEE, J.A., H. GERRITSEN \& W.P.M. RUIJTER, 1986. Transport and water quality modelling in the southern North Sea in relation to coastal pollution research and control.-Wat. Sci. Tech. 18: 245-256.

(received 14 May 1991; accepted 21 September 1992) 